\title{
Dlouhodobé kolísání průtoků Vltavy v Praze
}

LADISLAV KAŠPÁREK

Klíčová slova: průměrný průtok - reprezentativní období pozorování - periodicita průtoků - geomagnetický sluneční cyklus

\section{SOUHRN}

První část studie obsahuje doporučení pro výběr reprezentativního období pozorování pro výpočet charakteristik průměrných průtoků. Je to výsledek analýzy časové řady průtoků Vltavy v Praze s počátkem v roce 1801. V další části jsou zkoumány možnosti predikce 10letých klouzavých průměrů průtoku využívající autoregresní model. Je prokázáno, že 7leté nebo 10leté klouzavé průměry průtoků mají průběh podobný jako geomagnetický 22letý cyklus Slunce. Z korelace mezi průměrnými ročními průtoky a maximálními kulminačními průtoky vyplývá, že kolísání víceletých prưměrných průtoků z podstatné části odpovídá i výskytu a velikosti povodní.

\section{ÚVOD}

Charakteristiky průtoků jsou základem pro vodohospodářská řešení zásobování vodou, ochranu množství i kvality vod, stavební projekty na tocích i jejich okolí a řadu dalších oblastí hospodářských aktivit. Při jejich zpracování se často preepokládá, že proces, který popisují, je stacionární, takže charakteristiky popisující minulý stav jsou nejlepším odhadem stavu budoucího. Ve skutečnosti většinou potřebujeme poskytnout charakteristiky popisující poměry v konkrétním budoucím období o délce několika desetiletí, tedy dlouhodobou předpověd’. $\checkmark$ první kapitole studie je obsaženo doporučení pro volbu reprezentativního období, ze kterého se charakteristiky průměrných průtoků odvozují. V další části jsou zkoumány možnosti predpovědi trendu změn průměrných průtoků $\checkmark$ měřítku víceletých období. $V$ současné době, kdy se klimatické poměry dosti rychle mění, je třeba věnovat pozornost periodickým vlastnostem hydrologických procesů. Bez jejich uvážení se zvětšuje pravděpodobnost, že probíhajícím změnám přisoudíme neodpovídající vysvětlení.

\section{VÝZKUM VOLBY OBDOBÍ POUŽITÉHO PRO ZPRACOVÁNÍ CHARAKTERISTIK PRU゚TOKŮ}

Ve Výzkumném ústavu vodohospodářském byl řešen úkol Metody výpočtu hydrologických dat v měnících se podmínkách. Jedním z jeho výstupů byla výzkumná zpráva [1] a referát [2]. Výzkum byl zaměřen na problematiku volby návrhového období, používaného pro odvození charakteristik průměrných průtoků. Otázkou bylo, zda při narůstající délce pozorovaných řad má být reprezentativní období použité $v$ minulosti prodlužováno, nebo je vhodnější používat období o délce několika desítek let končící krátce před zpracováním charakteristik.

Při volbě reprezentativních období před rokem 1980 byla snaha využívat co nejdelší výchozí období pozorování. Při výběru období pro zpracování hydrologických charakteristik bylo vždy posouzeno, zda charakteristiky použitého období jsou dostatečně blízké charakteristikám vypočteným z nejdelších dostupných řad. Tato shoda byla používána jako argument pro oprávněnost volby užitého období. Tento prístup predpokládá, že řady jsou stacionární, takže odhad charakteristik z minulých řad za co nejdelší období je také nejvhodnějším odhadem pro budoucnost.

Zkoumání časových meteorologických a hydrologických řad i jevů, které mohou tyto řady ovlivnit, ukazuje, že kromě krátkodobých kolísání (v měřítku menším než 3-5 let) existují i dlouhodobé změny s časovým měřítkem desítky i stovky let. Jen $v$ omezené míre jsme schopni je identifikovat a matematicky popsat a ještě méně je umíme vysvětlit. Je velmi pravděpodobné, že většina takových kolísání má charakter, ovlivněný periodickými i náhodnými vlivy. Odhad hydrologických charakteristik ze zvoleného období může pak být citlivý na poměr délky i umístění reprezentativního období vzhledem k periodické složce průtokových řad.

Pro posouzení, jak délka reprezentativního období ovlivňuje chyby předpovědi průměrného průtoku na dobu 20 let, byla ve studii [1] použita řada průměrných ročních průtoků Vltavy v Praze z období 1801-1996. V použitém postupu simulujícím extrapolace průtoků v každém roce se předpokládá, že průměrný průtok z předchozích $\mathrm{N}$ let pozorování bude stejný i v následujících NP letech. Délka výchozí řady $N$ byla zvolena 20, 30, 40, 50, 60 a 70 let, délka předpovědního období NP byla zvolena 10, 20 a 30 let. Podle průměru absolutních hodnot odchylek takto extrapolovaného průměrného průtoku od pozorované hodnoty byla vyhledávána optimální délka návrhového období.

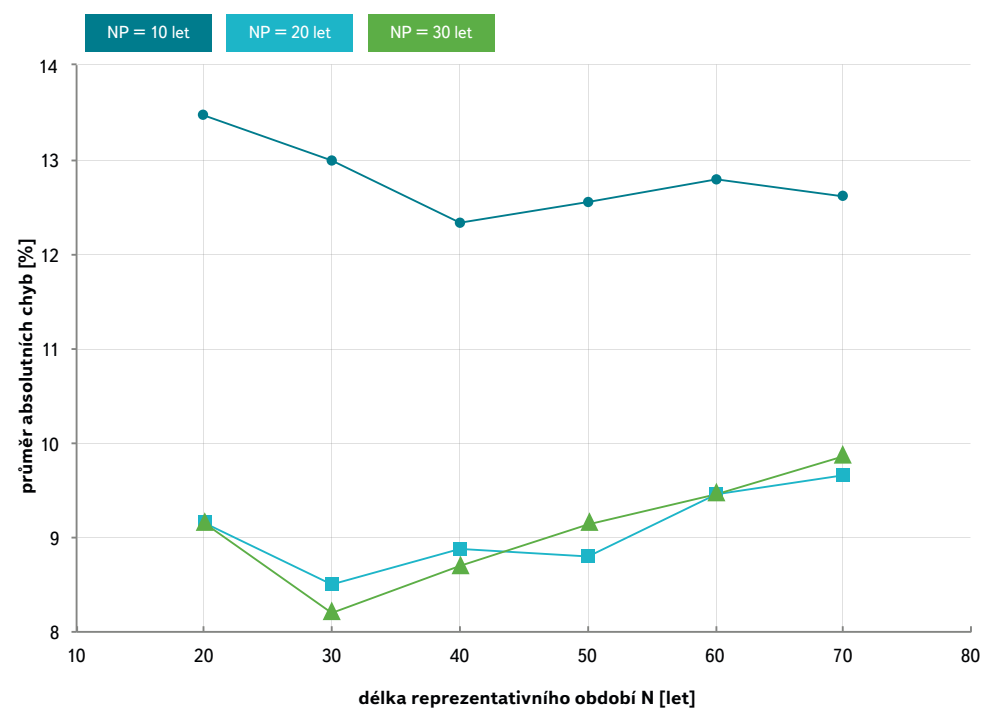

Obr. 1. Prưměry absolutních hodnot chyb předpovídaných průměrných průtoků pro období délky NP let získané z pozorování délky N let

Fig. 1. Average absolute deviation of the predicted average flow for the period length NP years derived from observation of length $N$ years 


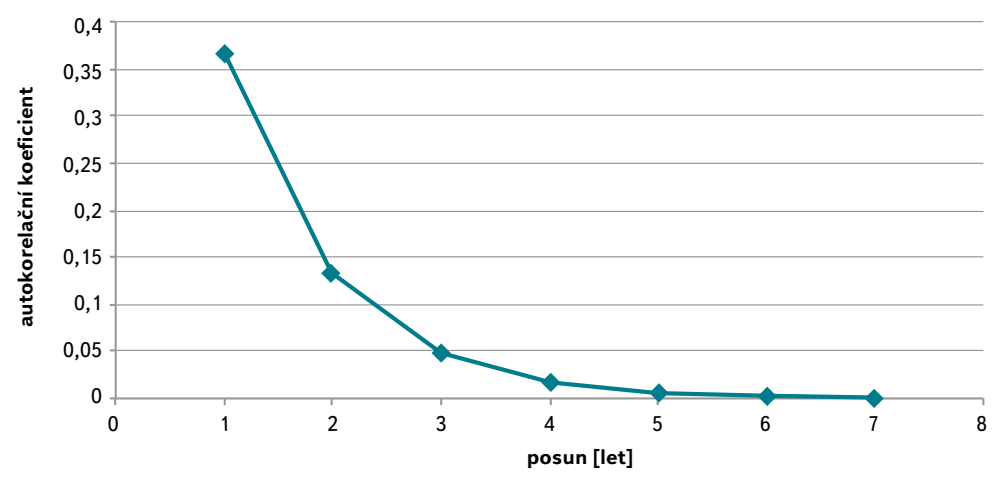

Obr. 2. Autokorelační funkce řady průměrných ročních průtoků rady 1801-1996 Fig. 2. Autocorrelation function of annual mean flow series for the period 1801-1996

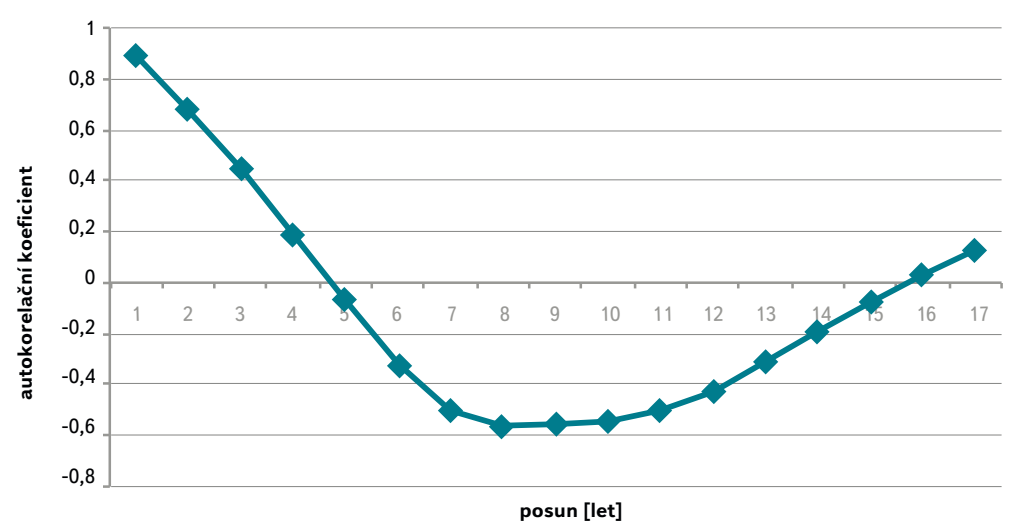

Obr. 3. Autokorelační funkce řady 10letých klouzavých průměrných průtoků 1801-1996 Fig. 3. Autocorrelation function of 10 -year moving averages of the annual mean flow series for the period 1801-1996

Na obr. 1 je vynesen prüměr absolutních hodnot chyb předpovědí pro uvedené délky NP v závislosti na délce výchozího období N. U délky předpovědního období NP = 10 let očividně převažuje vliv kolísání desetiletých průměrů nad vlivem délky výchozího období, nejmenší průměr absolutních hodnot je u trvání výchozího období $\mathrm{N}=40$ let. Průměr absolutních hodnot chyb prèpovědí je u trvání předpovědního období NP $=20$ a 30 let podstatně menší, pro délky výchozího období 30 let má minimum blízící se $8 \%$. Ze zobrazených výsledků byl vyvozen závěr: z hlediska soustavného vychýlení se jeví jako vhodnější výchozí období pro výpočet s kratšími délkami, přecházející době zpracování, podle průměru absolutních chyb o délce 30 až 40 let. Pro aktuální zpracování průměrných a m-denních průtoků v ČHMú bylo v souladu s tímto doporučením zvoleno období 1981-2010, viz [3].

\section{PERIODICKÉ SLOŽKY DLOUHODOBÉHO KOLÍSÁNÍ PRŮTOKŮ}

Součástí studie [1] byl také pokus ověrit, zda pro odhad průměrného průtoku za víceletá období Ize s prijiatelnou spolehlivostí použít extrapolaci využívající autokorelační vazby mezi ročními průměrnými průtoky.

$\checkmark$ průběhu klouzavých průměrů rad ročních průtoků a srážek se objevují prvky periodických kolísání. Ta můžeme popsat autokorelačním, resp. autoregresním modelem, pokud takový model uvažuje i vzdálenější autokorelační vazby mezi členy řady. Pro posouzení možností aplikace této metody pro odhad vývoje dlouhodobých změn průtoků na zvolené období jsme využili program [3].

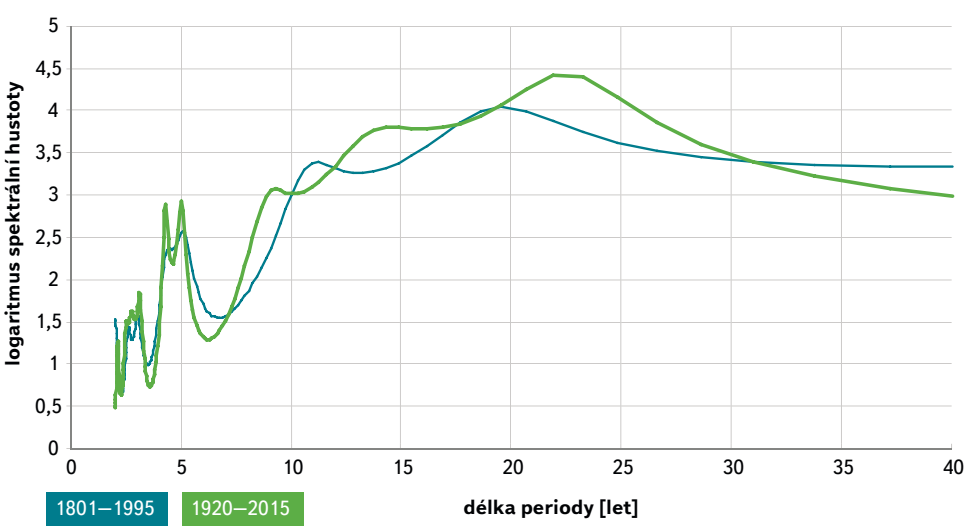

Obr. 4. Spektrální hustota 7letých klouzavých prưtoků vypočítaných z řad 1801-1995 a 1920-2015

Fig. 4. Spectral density of 7-year moving average flow calculated from the 1801-1995 and 1920-2015 series

Autokorelační funkce raady průměrných ročních průtoků na obr. 2 svědčí pouze o přenosu zásob vody z předcházejícího do následujícího roku, žádné vzdálenější vazby neukazuje. Z autokorelační funkce průtoků za víceletá období, např. ze sedmiletých klouzavých průměrů, Ize na periodické složky v průtokových řadách usuzovat, viz obr. 3.

Pro řady klouzavých prưměrů ročních průměrných průtoků s intervalem průměrování 2 až 15 let byly vypočteny spektrální hustoty. Pro každý interval průměrování byla vyhledána délka periody s maximální hodnotou spektrální hustoty. Výsledky shrnuje tabulka 1. Nejvýznačnější periody se při délkách průměrování méně než 10 let pohybují v rozmezí 16 až 19 let, při prưměrování 10 až 14 let délka periody soustavně stoupá od 19 do 25 let. Příklad průběhu spektrální hustoty pro sedmileté průměry ročních průměrných průtoků je na obr. 4. Podle tohoto grafu pro řadu obsahující i pozorování z 19. století je největší hodnota spektrální hustoty u délky periody 19 let, pro řadu od roku 1920 do 2015, kde je periodické kolísání zřetelnější, 22 let.

Program [4] poskytuje i délku období, na které je opodstatněné předpovídat (dosah předpovědi). Proměna této veličiny s délkou průměrování je patrná z tabulky 1. Pro intervaly průměrování od 9 do 14 let a také pro interval průměrování 7 let je dosah předpovědi podstatně větší, než pro intervaly prưměrování kratší nebo delší.

Pro řady klouzavých průměrů s intervalem průměrování 2 až 15 let byly $\checkmark$ roce 1996 vypočteny předpovědi autoregresním modelem, popsaným např́klad ve skriptech ČVUT [5]. Při výpočtech byl stupeň regrese zvolen 15, na délce průměrování zřejmě systematicky nezávisí, viz tabulka 1 .

Předpovědi pro průměry z období o délce $K=7,8,9,10$ a 11 let jsou na obr. 5 . Ukázalo se, že rámcově indikovaly dlouhodobé kolísání průtoků s koncem vodného období v letech 2003-2004 a s následujícím obdobím s menšími průtoky až do let 2011-2014. Výpočty ukazují, že předpověd' není zásadním způsobem ovlivněna tím, jaký interval průměrování použijeme, pokud bude z použitého rozmezí. 
Tabulka 1. Délka významných period a optimálni stupeň autoregresního modelu pro různé délky průměrováni r rady průtoků

Table 1. Significant period length and optimal degree of the autoregressive model for different averaging lengths of flow series

\begin{tabular}{|c|c|c|c|}
\hline $\begin{array}{l}\text { Interval } \\
\text { průměrování } \\
\text { [let] }\end{array}$ & Řád regrese & $\begin{array}{l}\text { Délky } \\
\text { periody } \\
\text { [let] }\end{array}$ & $\begin{array}{l}\text { Dosah } \\
\text { předpovědi } \\
\text { [let }]\end{array}$ \\
\hline 2 & 11 & 1) & 3 \\
\hline 3 & 14 & 17 & 4 \\
\hline 4 & 14 & 16 & 5 \\
\hline 5 & 11 & 17 & 6 \\
\hline 6 & 15 & 19 & 7 \\
\hline 7 & 15 & 19 & 24 \\
\hline 8 & 12 & 17 & 8 \\
\hline 9 & 12 & 17 & 22 \\
\hline 10 & 11 & 19 & 26 \\
\hline 11 & 13 & 20 & 24 \\
\hline 12 & 15 & 22 & 29 \\
\hline 13 & 15 & 23 & 28 \\
\hline 14 & 15 & 25 & 37 \\
\hline 15 & 12 & 1) & 16 \\
\hline
\end{tabular}

1) širokopásmové spektrum bez zřetelného maxima

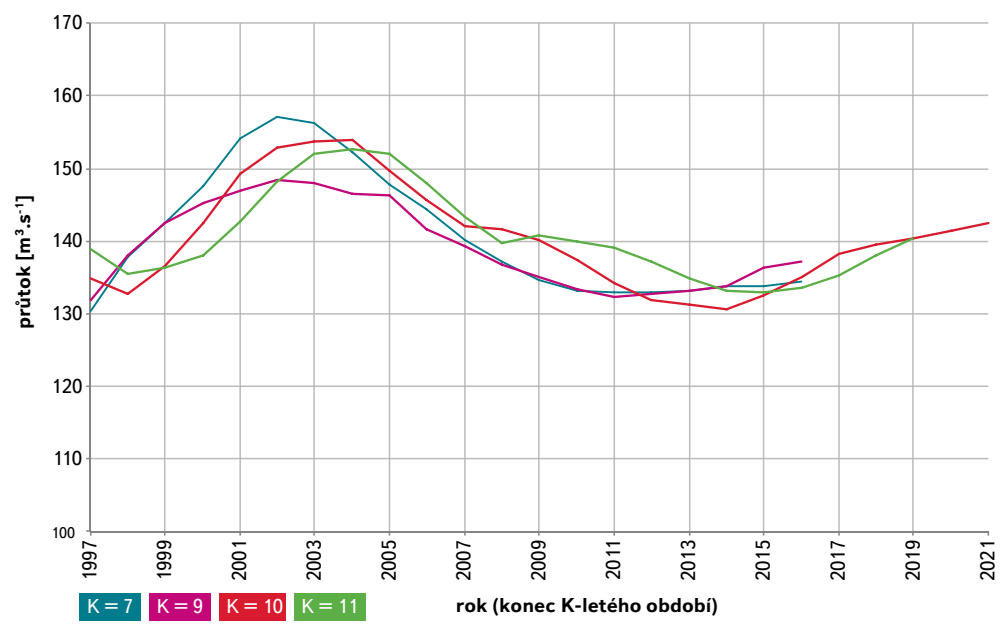

Obr. 5. Předpovědi K-letých průměrných průtoků vypočítané autoregresními modely Fig. 5. Predictions of K-year moving average flows calculated by autoregression models

V další etapě výzkumu jsme posoudili, zda při použití autoregresních předpovědí klouzavých průměrů (zvolili jsme délku průměrování 10 let) pro předpověd' na 10 let získáme předpovědi úspěšnější, než při předpovědi při extrapolaci předcházejícího průměrného průtoku. Autoregresní model se může lišit rádem, ale také volbou období, podle kterého jsou odvozovány autoregresní koeficienty. Dále uvedené výsledky jsou předpovědi desetiletých klouzavých průměrů podle autokorelačních koeficientů odvozených z celé řady 1801-1995. Řád regrese byl zvolen 11 let. Numerický pokus simuloval predpověd’ zpracovanou $\checkmark$ každém roce od dvanáctého roku řady. Výstupem programu jsou předpovědi desetiletých klouzavých průměrů na NP následujících let. Pro posouzení, zda použití regresních předpovědí vede k lepším odhadưm, než předpověd’ podle průměru předcházejícího období nebo než užití konstantního dlouhodobého průměru, byl vypočten pro každou predpověd" průměr absolutních hodnot odchylek předpovědí od pozorovaných hodnot za předpovídané období. Tyto charakteristiky chyb byly pro každý rok porovnány s analogicky vypočtenými ukazateli "setrvalých“ předpovědí podle předcházejícího průměrného průtoku za 10 let a s analogicky vypočtenými ukazateli odchylek pozorovaných průtoků od dlouhodobého průměru. Extrémy průměrů odchylek jsou u regresních predpovědí znatelně menší, než u odchylek od dlouhodobého průměru, totéž platí (i když méně výrazně) pro porovnání s průměry odchylek předpovědí podle předcházejícího průměru. Pro výsledné porovnání byly vypočteny průměry z průměrných absolutních hodnot odchylek ze všech předpovědí v jednotlivých letech pro použité predpovědní postupy. Jsou uvedeny v tabulce 2 a ukazují, že regresní předpovědi v průměru vedou k menším odchylkám.

Tabulka 2. Porovnání prüměrů absolutnich hodnot chyb předpovědi podle rưzných postupư výpočtu

Table 2. Comparison of averages absolute forecast errors according to different calculation procedures

\section{Postup výpočtu předpovědi}

Průmèr absolutních hodnot odchylek $\left[\mathrm{m}^{3} \cdot \mathrm{s}^{-1}\right]$

\begin{tabular}{ll}
\hline dlouhodobý průměr & 14,55 \\
\hline předcházející desetiletý průměr & 10,23 \\
\hline autoregresní funkce & 8,21
\end{tabular}

V současné době uplynulo od zpracování výše popsaných výpočtů předpovědí 18 let, takže můžeme posoudit, zda předpovědi podle autoregresního modelu mohly poskytnout alespoň částečně použitelné informace o vývoji průměrných průtoků Vltavy v Praze. Na obr. 6 jsou zobrazeny průběhy předpovězené a průběhy vypočítané podle pozorování, pro délky průměrování $K=7$ a 10 let. Z obrázku je patrné, že do roku 2004 vystihly u obou délek průměrování postupný nárůst průměrných průtoků. Předpověd” pro $K=7$ se nijak zásadně neodchyluje od pozorovaného průběhu. $V$ pokračujícím úseku řady po roce 2005 předpovědi sice indikují postupný rámcový pokles průměrných průtoků až do roku 2015, v absolutních velikostech průtoku jsou však realitě značně vzdálené. Z těchto výsledků můžeme usuzovat, že prededpovědi autoregresním modelem mohou poskytnout použitelné informace jen s predstihem několika let.

Podle tohoto poznatku jsme vypočítali simulaci předpovědí sedmiletých průměrných průtoků autoregresním modelem $v$ dvouletém intervalu počínaje rokem 2002, vždy na následujících 5 let. Takto vypočítané průběhy spolu s průběhem sedmiletých průměrných průtoků podle pozorování jsou na obr. 7 . Předpovědi by $v$ posuzovaném období príijatelně indikovaly dlouhodobé tendence změn průměrných průtoků.

Možnostmi dlouhodobých predpovědí pomocí harmonického modelu PYTHIA a autoregresního modelu klouzavých průtoků se zabývala Pekárová [6]. Podle výsledků z modelu PYTHIA má být víceleté suché období 2013-2020. Výrazně průtokově podprưměrné roky v období po roce 2015 předpovídal i sezonní autoregresní model (SARIMA) [6]. 


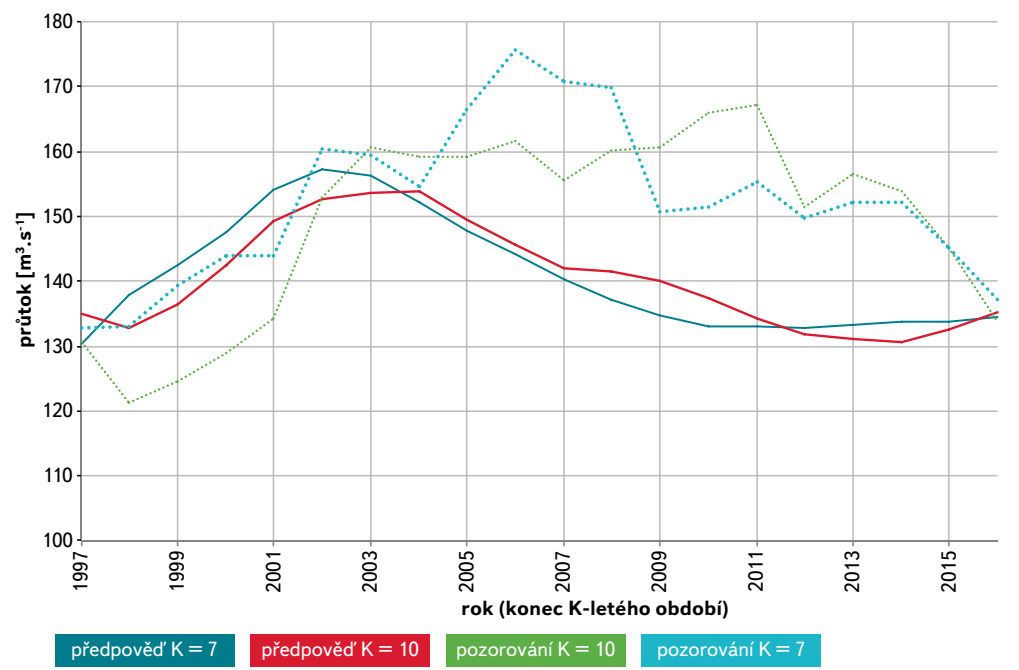

Obr. 6. Předpovědi klouzavých průtoků K-roků vypočtených v roce 1996 autoregresními modely ve srovnání s pozorovanými hodnotami

Fig. 6. Predictions of K-years moving average flows calculated in 1996 by autoregressive models compared with observed values

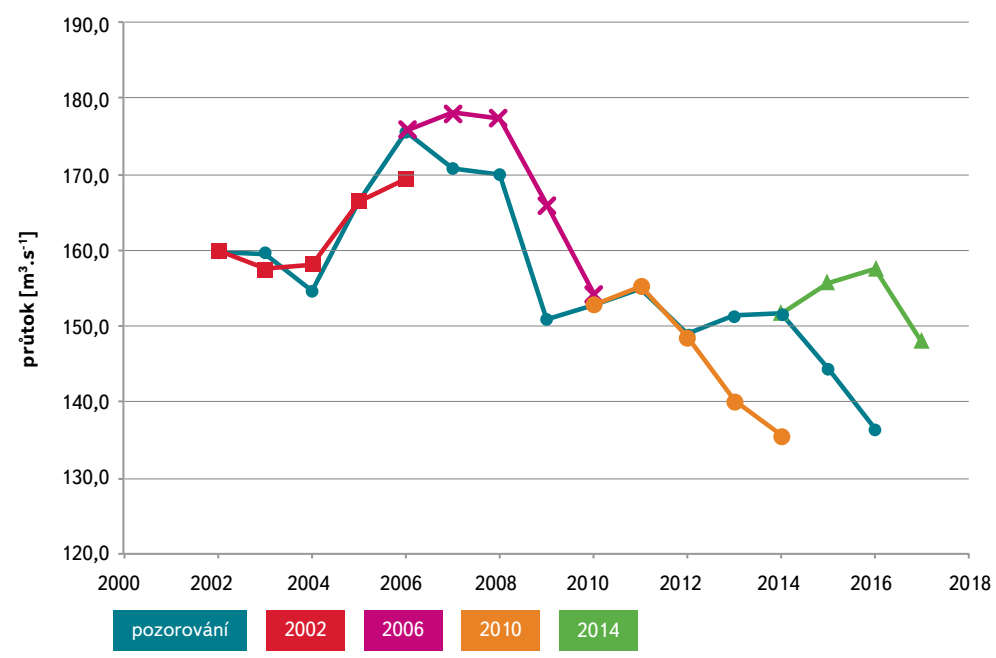

Obr. 7. Simulace postupných předpovědí průměrných sedmiletých průtoků vypočítané po dvou letech, s predstihem 1 až 5 let

Fig. 7. Simulation of successive predictions of 7-year moving average flow calculated every two years with forecast horizon 1 to 5 years

\section{SOUVISLOSTI DLOUHODOBÉHO KOLÍSÁNÍ PRŮTOKŮ S GEOMAGNETICKÝM SLUNEČNÍM CYKLEM}

Před rokem 1965 zpracoval Bratránek [7] předpověd’ výskytu maxim a minim průměrných ročních průtoků Vltavy v Praze podle postupu, v kterém se používaly časové vazby mezi průběhem počtu slunečních skvrn a výskytem extrémů ročních průměrných průtoků. Obrázek 8 ukazuje, že jeho predpověd' byla úspěšná. Při pokusech o další aplikace jím navrženého postupu jsme shledali, že předpokládané časové relace se dlouhodobě nezachovávají.

Podle obr. 4 je pro sedmileté klouzavé průměry pro radu průtoků Vltavy $\checkmark$ Praze s počátkem v roce 1801 charakteristická perioda s délkou 19 let, v pozdějším období 22 let, u řad průměrných ročních srážek podle [1] také 22 let, což je dvojnásobek střední délky jedenáctileté periody kolísání počtu slunečních

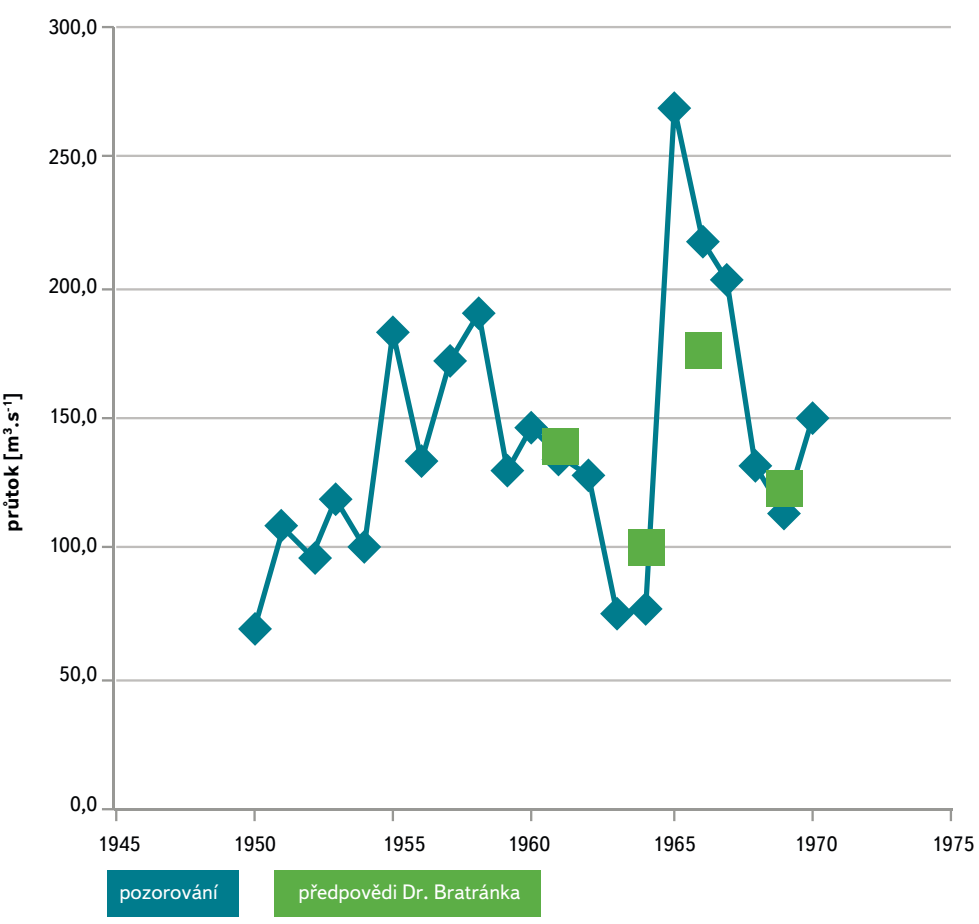

Obr. 8. Průběh průměrných ročních průtoků Vltavy v Praze a predikce vypočítané Bratránkem [7]

Fig. 8. Average annual flow of the VItava River in Prague and the prediction calculated by Bratránek [7]

skvrn. Délku periody 22 let má Haleův cyklus magnetického pole Slunce, který vyplývá z toho, že vždy za 11 let se magnetické pole Slunce přepóluje a za dalších 11 let se přepóluje zpět, viz [8]. Pro posouzení zda dlouhodobé kolísání průtoků Vltavy může souviset s Haleovým cyklem, jsme raadu počtu slunečních skvrn transformovali tak, že počty každého druhého cyklu jsme vynásobili číslem -1. Takto získaný průběh je na obr. 9 zobrazen společně s průběhem sedmiletých klouzavých průměrů ročních průměrných průtoků, obě veličiny jsou transformované na směrodatné proměnné. Ze sedmi cyklů z období 1851-2015 Ize $v$ pěti shledat př́znaky podobnosti. Koeficient korelace mezi pořadnicemi magnetického cyklu a klouzavými průměrnými sedmiletými průtoky je 0,61. Můžeme tedy usuzovat, že kolísání průtoků v použitém měřítku nějakým způsobem, který neznáme, souvisí s geomagnetickým Haleovým cyklem Slunce.

\section{Poznámka}

Pro výše uvedené posouzení jsme použili řadu průtoků Vltavy s počátkem $\checkmark$ roce 1851. Důvodem je př́lišná nejistota, kterou je zatížena předcházející část řady, na kterou upozornila studie viz [7]. Ke stejnému závěru vedly i výsledky modelování hydrologické bilance, provedené v rámci současných prací. 


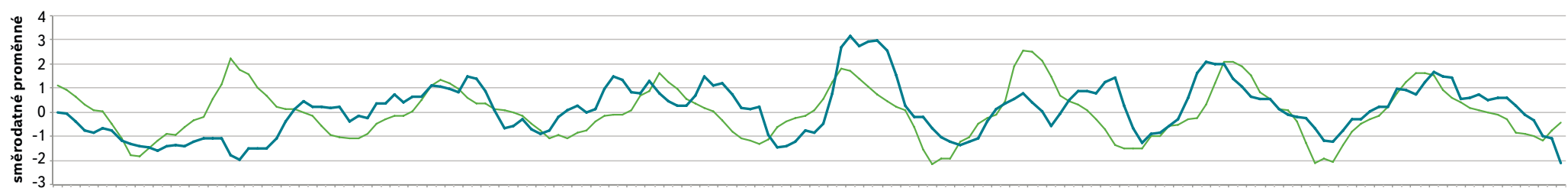

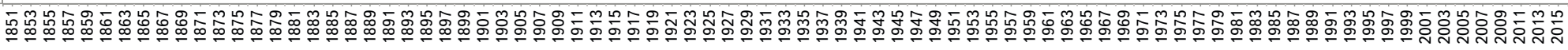
počet slunečnich skvrn prütok - 7letý klouzavý průmě

Obr. 9. Časový průběh směrodatných proměnných magnetického cyklu Slunce a sedmiletých klouzavých průměrů průtoků Vltavy

Fig. 9. Time series of the standardized variables of the magnetic cycle of the Sun and seven-year moving averages flow in the VItava River

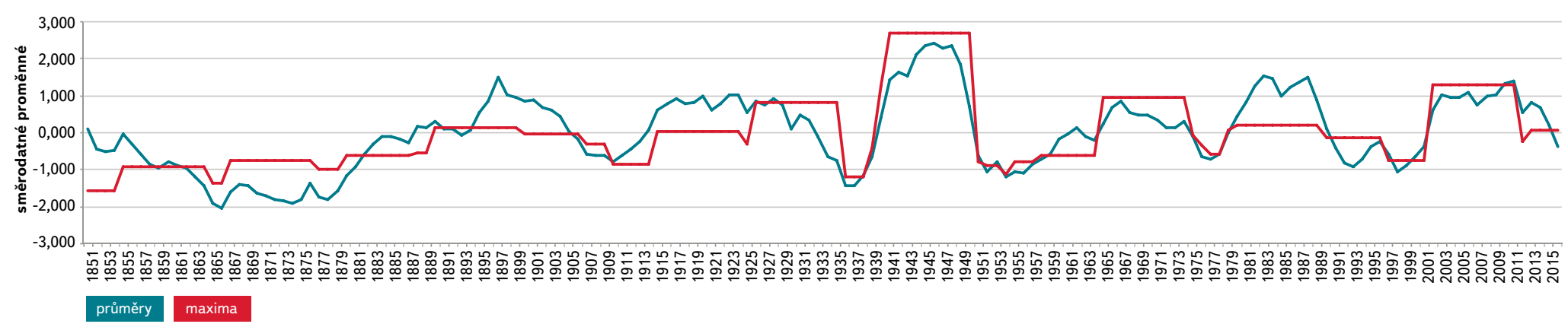

Obr. 10. Standardizované proměnné vypočtené z 10letých klouzavých průměrů průměrných ročních průtoků a z maximálních ročních průtoků v desetiletých obdobích

Fig. 10. Standardized variables calculated from 10-year moving average annual flow and from 10-year running maxima of the annual flow

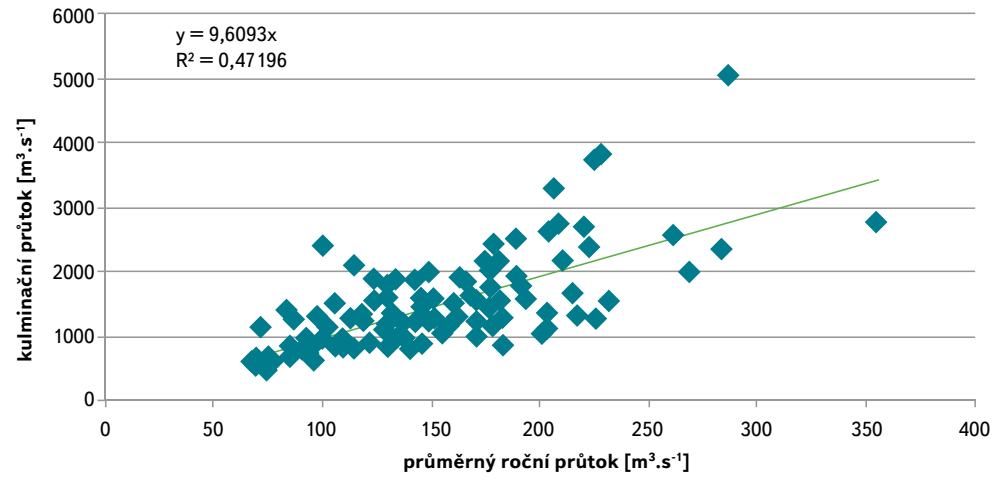

Obr. 11. Korelační vztah mezi průměrnými ročními průtoky a maximálními kulminačními průtoky

Fig. 11. Correlation between the average annual flow and the maximum flood peak flows

\section{VZTAH MEZI DLOUHODOBÝM} KOLÍSÁNÍM PRŮMĚRNÝCH PRU゚TOKŮ A KULMINAČNÍCH PRU゚TOKŮ POVODNÍ

Kolísání víceletých průměrných průtoků za sedmileté nebo desetileté období je závislé především na výskytech mimořádně velké hodnoty jednoho nebo i několika ročních průměrných průtoků. Průběh směrodatných proměnných klouzavých průměrů za desetiletá období, vypočítaných z průměrných ročních průtoků a z maxim průměrných ročních průtoků na obr. 10 jsou podobné.

Podstatnou část variability ročních průtoků Ize vysvětlit maximálními kulminačními průtoky jako ukazateli výskytu povodní. Svědčí o tom regresní vztah mezi průměrnými ročními průtoky a maximálními kulminačními průtoky v roce na obr. 11, který je charakterizován koeficientem korelace 0,687. Také koeficient korelace vztahu mezi desetiletými klouzavými průměrnými průtoky

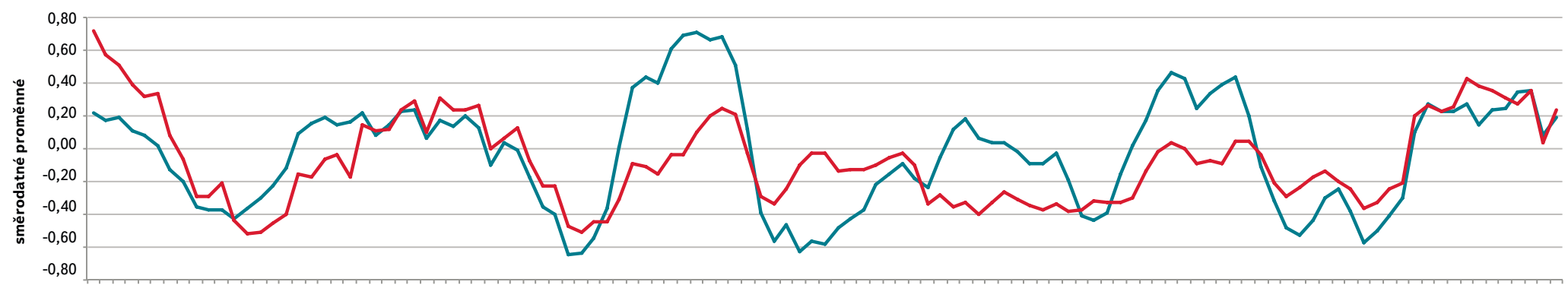

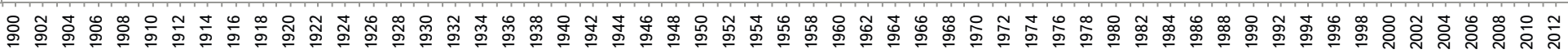
průměry

Obr. 12. Průběh desetiletých klouzavých průměrů směrodatných proměnných průměrných ročních průtoků a maximálních kulminačních průtoků

Fig. 12. Moving average of the standardised average annual flow and maximum flood peak flows 
a desetiletými klouzavými průměry kulminačních průtoků má hodnotu 0,599. I kolísání desetiletých průměrných průtoků je tedy podstatně určováno výskytem a velikostí povodní. Ukazuje se to také na obr. 12, kde jsou průběhy klouzavých průměrů směrodatných proměnných průměrných ročních průtoků a maximálních kulminačních průtoků.

\section{ZÁVĚR}

Při volbě reprezentativního období se jeví jako vhodnější využívat období o délce 30 až 40 let přecházející době zpracování, než prodlužovat dříve používaná období (napríklad 1931-1980) do současnosti.

V řadě průtoků Vltavy v Praze se při použití víceletých klouzavých průměrů projevují periodické složky kolísání. Autoregresním modelem Ize na tomto základě předpovídat budoucí vývoj vodnosti, s předstihem např́klad 5 let. Předpovídat Ize jen několikaleté průměry, nikoliv jednotlivé roční průměry.

Periodické kolísání víceletých průměrných průtoků je dosti podobné a většinou synchronní s průběhem 22letého geomagnetického cyklu Slunce.

Velikost průměrných ročních průtoků i víceletých průměrných průtoků je podstatně závislá na výskytu a velikosti povodní, takže kolísání průtokư $\checkmark$ měřítku víceletých období je projevem kolísání režimu povodní. Tato vazba je patrná, i když povodně popisujeme jen kulminačním průtokem.

\section{Literatura}

[1] KAŠPÁREK, L. Metody zpracování dat v nestacionárních podmínkách. Výzkumná zpráva. Praha: Výzkumný ústav vodohospodářský T. G. Masaryka, 1998, 24 s.

[2] KAŠPÁREK, L. Vliv kolísání klimatu na postup výpočtu návrhových hydrologických dat. In: Hydrologické dny - nové podněty a vize pro príištís století. Plzeň: ČHMÚ, Plzeň, 2000, s. 257-263.

[3] BUDÍK, L., ŠERCL, P., KUKLA, P., LETT, P. a PECHA, M. Odvození základních hydrologických údajů za referenční obdobi 1981-2010. Praha: ČHMÚ, 2014,72s.

[4] PRIVALSKI, V. and JENSEN, D.T. Time analysis package. Logan, Utah: Climate Center, 1989, $61 \mathrm{~s}$

[5] VOTRUBA, L. a NACHÁZEL, K. Základy teorie stochastických procesů a jejich aplikace ve vodním hospodárství. Skripta. Praha: ČVUT, 1971, s. 147-148.

[6] PEKÁROVÁ, P. Dynamika kolísání odtoku svetových a slovenských tokov. Bratislava: VEDA, 2003, 222 s. ISBN 80-224-0780-1.

[7] BRATRÁNEK, A. Sluneční aktivita a její vliv na kolísání hydrologických jevů. Práce a studie sešit 117. Praha: VÚVTGM, 83 s.

[8] KIPPENHAHN, R. Odhalená tajemství slunce. Mladá fronta. Praha: Mladá fronta, Edice Kolumbus, SV. 147, 1999, s. 99.

\section{Autor}

Ing. Ladislav Kašpárek, CSc.

凶ladislav.kasparek@vuv.cz

Výzkumný ústav vodohospodářský T. G. Masaryka, v. v. i.

Příspěvek prošel lektorským řízením

\section{LONG-TERM FLUCTUATIONS OF VLTAVA RIVER FLOWS IN PRAGUE}

\section{KASPAREK, L.}

TGM Water Research Institute, p. r. i.

Keywords: mean flow - representative observation period periodicity of flows - the geomagnetic cycle of the Sun

The first part the present study contains recommendations for the selection of representative observation period used for the calculation of average flow characteristics. This is the result of calculations based on time series of flows of the VItava River in Prague with beginning in 1801. In the next part the possibilities of prediction of 10-year moving average flow are examined using an autoregressive model. It is shown that 7-year or 10-year moving average flow is similar to that of the geomagnetic 22-year cycle of the Sun. From the correlation between the mean annual flows and the maximum flood flows follows that even the fluctuation of the multi-annual average flow rates to a large extent correspond to flood occurrence and magnitude. 